\title{
Pleural coccidioidomycosis
}

\author{
Timothy M Saettele, Carlos A Jimenez
}

Department of Pulmonary Medicine, MD Anderson Cancer Center, Houston, Texas, USA

\section{Correspondence to}

Dr Carlos A Jimenez,

cajimenez@mdanderson.org

Accepted 2 November 2014

\section{DESCRIPTION}

A 54-year-old man presented for evaluation of suspected metastatic lung cancer. He had been treated with multiple courses of antibiotics over the previous year for waxing-and-waning flu-like symptoms. A positron emission tomography CT scan performed 5 months previously showed a hypermetabolic $1.9 \mathrm{~cm}$ right middle lobe nodule with associated right hilar, right paratracheal and subcarinal lymphadenopathy (figure 1). A percutaneous biopsy of the right middle lobe nodule was nondiagnostic. Subsequently, the patient developed a large right pleural effusion and was referred to obtain tissue for diagnosis.

Thoracentesis was performed with drainage of $1050 \mathrm{~mL}$ of slightly red fluid. The fluid was exudative, and cytological evaluation was negative for malignancy. Gram stain and culture for bacterial, fungal and acid-fast organisms were unremarkable. Medical pleuroscopy was performed (video 1) and demonstrated thickening and erythema of the parietal pleura with multiple nodules studding the posterolateral pleura and diaphragm (figure 2). Biopsies taken from this area showed Coccidioides spp in a background of necrotising granulomatous

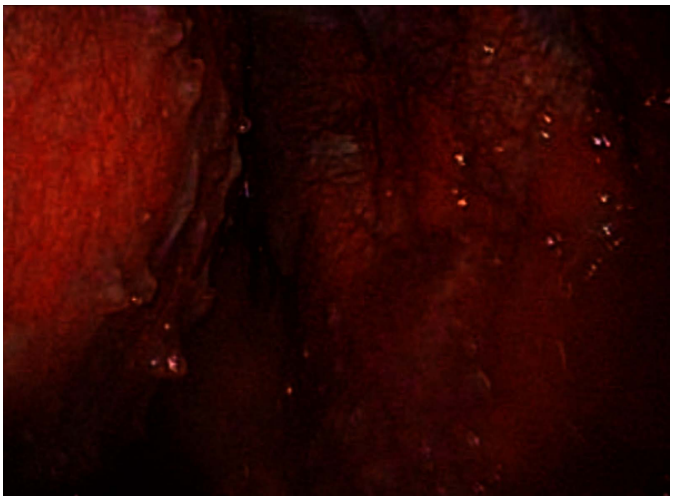

Video 1 The pleuroscopy procedure demonstrating the described findings associated with pleural coccidioidomycosis.

inflammation (figure 3). The patient began treatment with fluconazole, which will be continued for at least 6 months.

Coccidioides spp are two fungal organisms $(C$ immitis and $C$ posadasii) endemic to deserts in the southwest USA, Mexico and Central America. Infection may occur following inhalation of airborne arthroconidia. Pulmonary coccidioidomycosis can

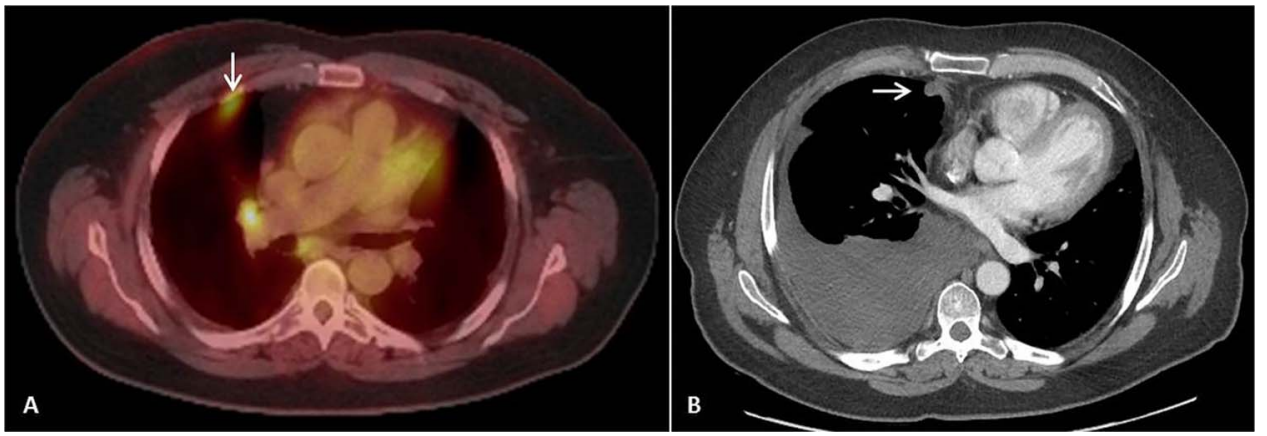

Figure 1 (A) Integrated positron emission tomography-CT scan showing increased metabolic activity in a right middle lobe nodule (arrow) and subcarinal and right hilar lymph nodes. (B) Chest CT scan performed 4 months later demonstrates a new large right pleural effusion and a stable right middle lobe nodule (arrow). 


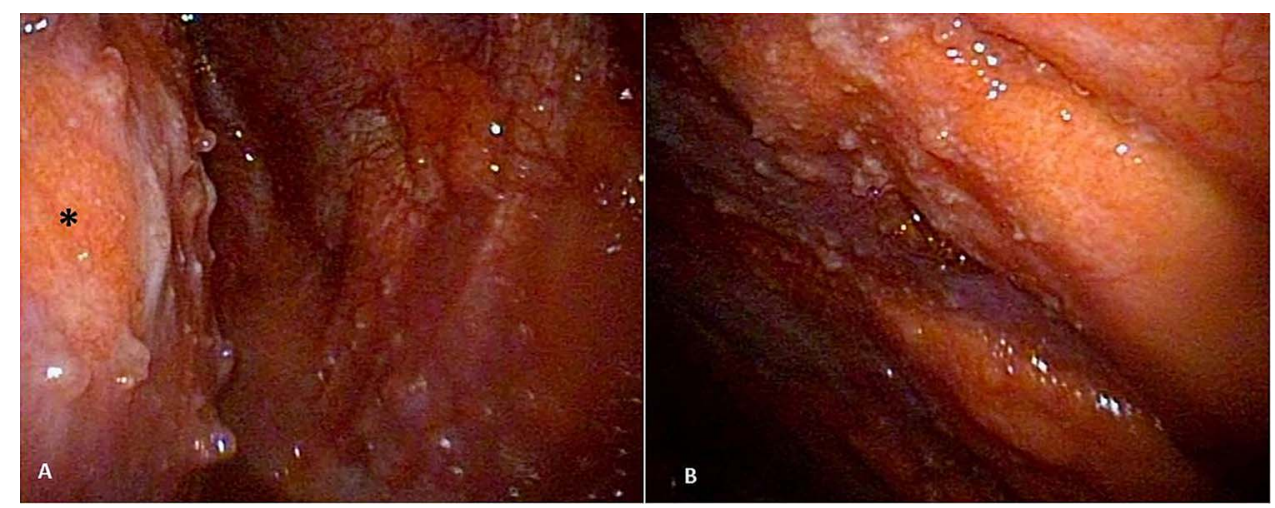

Figure 2 Pleuroscopic views of nodular studding along (A) the diaphragm $\left({ }^{*}\right)$, lateral parietal pleura and (B) posterior parietal pleura. The pleura appears thickened and erythematous.

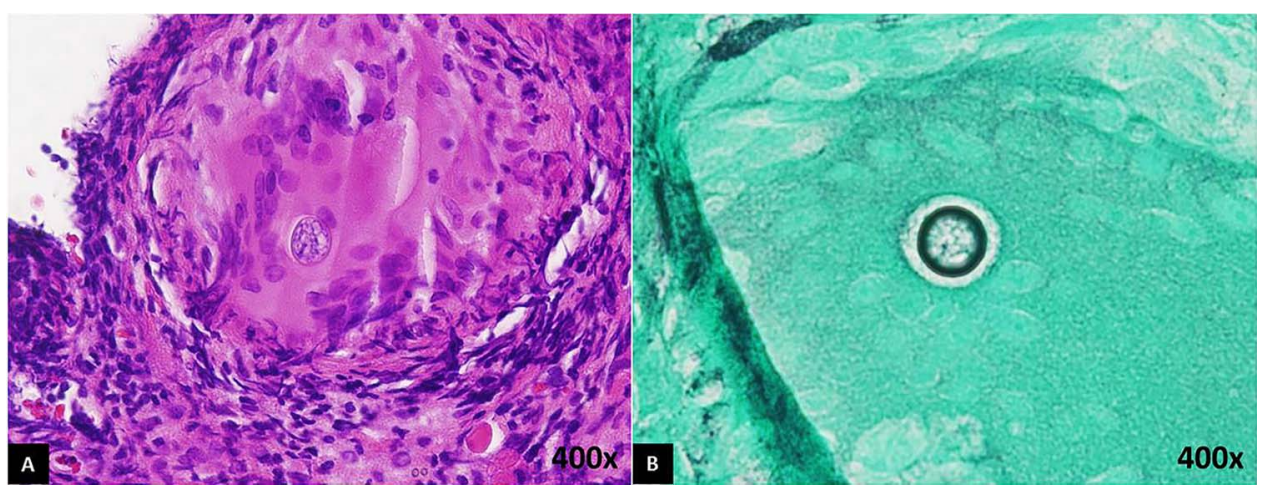

Figure 3 (A) Photomicrographs of parietal pleura biopsy specimens stained with (A) H\&E and (B) Gomori methenamine silver. Granulomatous inflammation is seen surrounding spherules of Coccidioides. Close examination reveals endospores present in the spherules.

present with a variety of radiological findings that mimic lung cancer. Pleural effusions occur in as many as $10 \%$ of patients. ${ }^{1}$ The diagnosis is occasionally made by thoracentesis, but often pleural biopsy is necessary. ${ }^{2}$

\section{Learning points}

- Pulmonary coccidioidomycosis can present with a variety of radiological findings that mimic lung cancer, including parenchymal nodules and infiltrates, hilar and mediastinal lymphadenopathy, and pleural effusions.

- Although the diagnosis of pleural coccidioidomycosis is occasionally made by pleura fluid analysis, biopsy of the parietal pleural is often necessary.
Contributors TMS and CAJ performed medical pleuroscopy and participated in patient management and follow-up. TMS and CAJ were involved in the preparation of the manuscript.

Competing interests None.

Patient consent Obtained.

Provenance and peer review Not commissioned; externally peer reviewed.

\section{REFERENCES}

1 Johnson RH, Caldwell JW, Welch G, et al. The great coccidioidomycosis epidemic: clinical features. Paper presented at Proceedings of the 5th International Conference; 24-27August 1994; Palo Alto, CA. Bethesda: National Foundation for Infectious Diseases; 1996. p. 77-87.

2 Spinello IM, Munoz A, Johnson RH. Pulmonary coccidioidomycosis. Semin Respir Crit Care Med 2008;29:166-73.

Copyright 2014 BMJ Publishing Group. All rights reserved. For permission to reuse any of this content visit http://group.bmj.com/group/rights-licensing/permissions.

BMJ Case Report Fellows may re-use this article for personal use and teaching without any further permission.

Become a Fellow of BMJ Case Reports today and you can:

- Submit as many cases as you like

- Enjoy fast sympathetic peer review and rapid publication of accepted articles

- Access all the published articles

- Re-use any of the published material for personal use and teaching without further permission

For information on Institutional Fellowships contact consortiasales@bmjgroup.com

Visit casereports.bmj.com for more articles like this and to become a Fellow 